\section{Noticias y comentarios}

ser el exponente de procesos (históricos, urbanísticos, tecnológicos).

Esta modalidad de protección se ha aplicado a otros tipos de Patrimonio (arqueológico, preindustrial, jardines) en los que convergen características de implantación -territorial, cronológica, tipológica- o en los que no es necesario la delimitación de un entorno adicional. La catalogación genérica colectiva aporta una visión cultural de un territorio que ha sido soporte de distintos pueblos que han interactuado con él. La aplicación de esta figura conlleva realizar un trabajo de síntesis territorial e histórica que nos aportará el leit motiv cultural de la zona.

Los 145 elementos del Parque Natural de Cabo de Gata-Níjar y los 63 de la Cultura del Agua de la comarca de los Vélez revelan la singularidad cultural de esta zona árida del sudeste de la Península. La estructura social y económica de estos territorios, la estabilidad de los sistemas hidráulicos, las técnicas de cultivo y aprovechamientos tradicionales han permitido que este conjunto de bienes haya estado en uso continuado hasta hace muy poco, modelando el paisaje por los contrastes de vegetación que introducian a través de los cultivos asociados. El viento y el agua en la construcción de un paisaje cultural. Parque Natural de Cabo de GataNijar y de la comarca de los Vélez (Almería) es el título editorial de la Consejería de Cultura que pretende presentar la importancia de unos bienes etnológicos que constituyen una buena muestra de la tecnología tradicional hidráulica, ya que aparecen representadas las tipologías relacionadas con la extracción (norias), trans- porte (acequias, acueductos), aprovechamiento (molinos, molinas, lavaderos), consumo (abrevaderos, fuentes) y el almacenaje del agua (aljibes, tanques y cisternas). Estos bienes etnológicos, que son hoy marcadores identitarios de los almerienses, permanecen profundamente arraigados en su memoria colectiva, recordándoles un pasado cercano dominado por una férrea voluntad de supervivencia. Son, además, un valioso testimonio de las diferentes culturas asentadas sobre este medio.

Otro de los últimos títulos presentados por Cultura, Jornadas de patrimonio y territorio: actas, recoge las conferencias e intervenciones que tuvieron lugar en las jornadas celebradas entre los dias 13 y 15 de marzo de 2003 en la ciudad de Úbeda (Jaén). Dichas jornadas estaban dirigidas no sólo a geógrafos, como profesionales estudiosos del territorio, y a técnicos de la cultura, sino a todos aquellos profesionales, agentes locales, organismos e instituciones regionales, provinciales y locales vinculados a la gestión del patrimonio y del desarrollo.

\section{Adquisiciones:}

Empresa Pública de Gestión de Programas Culturales

Dpto. Distribución Editorial

Tel.: 955037264

Fax: 955037265

Web: www.juntadeandalucia.es/cultura

Correo-e.: lidia.ros@juntadeandalucia.es

\title{
La asociación Saxoférreo premia una investigación sobre patrimonio hidráulico
}

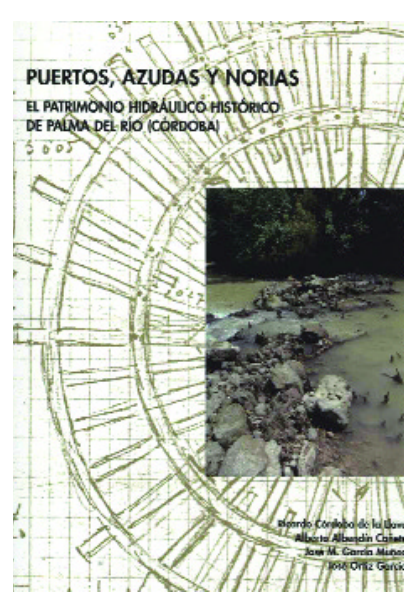

Uno de los elementos más desconocidos del patrimonio cultural en el mundo rural es el que constituye todo el proceso de captación y repartición del agua en las hasta hoy escasas tierras de regadío. El paisaje agrario de Palma del Río (Córdoba), dividido en pagos de huertas y sus productos citricolas, ha permitido conservar algunas pruebas de las antiguas formas de utilización del agua. La existencia de este peculiar paisaje agrario puede remontarse a la época andalusí y, siempre unido a ella, ha estado un interesante patrimonio cultural que merece ser conservado. Ésta es la conclusión fundamental de un libro que aporta apreciables testimonios sobre ese legado de Al-Andalus.

La obra Puertos, azudas y norias. El Patrimonio Hidráulico de Palma del Río es fruto del proyecto de investigación ganador de la segunda beca convocada por la asociación Saxoférreo (www.saxoferreo.com) y la Fundación El Monte, entidades editoras. El libro, dividido en dos capítulos fundamentales que estudian las obras hidráulicas relacionadas con los riegos agrícolas y las obras que servian para el aprovechamiento industrial, profundiza en el análisis y catalogación de los testimonios de ese rico patrimonio hidráulico, compuesto por sistemas de riego, molinos harineros, norias y azudas.

Emilio Navarro

Asociación Saxoférreo 